\title{
Validating a spatially distributed hydrological model with soil morphology data
}

\author{
T. Doppler ${ }^{1,2}$, M. Honti ${ }^{1}$, U. Zihlmann ${ }^{3}$, P. Weisskopf ${ }^{3}$, and C. Stamm ${ }^{1}$ \\ ${ }^{1}$ Swiss Federal Institute of Aquatic Science and Technology (Eawag), Dübendorf, Switzerland \\ ${ }^{2}$ Swiss Federal Institute of Technology (ETH), Zürich, Switzerland \\ ${ }^{3}$ Agroscope Reckenholz-Tänikon, Zürich, Switzerland \\ Correspondence to: C. Stamm (christian.stamm@eawag.ch)
}

Received: 13 August 2013 - Published in Hydrol. Earth Syst. Sci. Discuss.: 30 October 2013

Revised: 18 July 2014 - Accepted: 30 July 2014 - Published: 9 September 2014

\begin{abstract}
Spatially distributed models are popular tools in hydrology claimed to be useful to support management decisions. Despite the high spatial resolution of the computed variables, calibration and validation is often carried out only on discharge time series at specific locations due to the lack of spatially distributed reference data. Because of this restriction, the predictive power of these models, with regard to predicted spatial patterns, can usually not be judged.

An example of spatial predictions in hydrology is the prediction of saturated areas in agricultural catchments. These areas can be important source areas for inputs of agrochemicals to the stream. We set up a spatially distributed model to predict saturated areas in a $1.2 \mathrm{~km}^{2}$ catchment in Switzerland with moderate topography and artificial drainage. We translated soil morphological data available from soil maps into an estimate of the duration of soil saturation in the soil horizons. This resulted in a data set with high spatial coverage on which the model predictions were validated. In general, these saturation estimates corresponded well to the measured groundwater levels.

We worked with a model that would be applicable for management decisions because of its fast calculation speed and rather low data requirements. We simultaneously calibrated the model to observed groundwater levels and discharge. The model was able to reproduce the general hydrological behavior of the catchment in terms of discharge and absolute groundwater levels. However, the the groundwater level predictions were not accurate enough to be used for the prediction of saturated areas. Groundwater level dynamics were not adequately reproduced and the predicted spatial saturation patterns did not correspond to those estimated from the
\end{abstract}

soil map. Our results indicate that an accurate prediction of the groundwater level dynamics of the shallow groundwater in our catchment that is subject to artificial drainage would require a model that better represents processes at the boundary between the unsaturated and the saturated zone. However, data needed for such a more detailed model are not generally available. This severely hampers the practical use of such models despite their usefulness for scientific purposes.

\section{Introduction}

Spatially distributed models are popular tools in hydrology. They are claimed to be useful for supporting decisions in water resources management (e.g. Lyon et al., 2006; Heathwaite et al., 2005; Frey et al., 2009; Agnew et al., 2006). Despite the high spatial resolution of the computed variables, calibration and validation is often carried out only on discharge time series at specific locations due to the lack of spatially distributed reference data (Srinivasan and McDowell, 2009). Furthermore, distributed models typically have a large computational demand because calculations are performed on several tens of thousands or hundreds of thousands of cells. This huge resource requirement prevents meaningful uncertainty analysis that would require ten thousands of model runs. The predictive power of these models, with regard to predicted spatial patterns, can usually not be judged because of these restrictions.

An application of spatial predictions in hydrology is the forecast of critical source areas (CSAs) for diffuse pollution in agricultural areas (Pionke et al., 1996). Several 
studies have shown that the contributions of different fields within a catchment to diffuse pollution can differ significantly (Gomides Freitas et al., 2008; Leu et al., 2004b; Louchart et al., 2001). This implies that a relatively small proportion of a catchment can cause the major part of surface water pollution. An area has to be hydrologically active to be a CSA. Under typical Swiss climatic and topographic conditions and for most pollutants except for nitrate, this means areas where surface runoff and/or macropore flow occur (Pionke et al., 1996).

If CSAs can be reliably predicted, this offers efficient mitigation options, because actions on a small proportion of the area can strongly reduce the substance input to the stream. Basically there are two strategies to identify CSAs. They can be identified in the field or recognized from predictions by a model that captures the dominant features of the underlying mechanisms. The identification in the field is rather time consuming; it requires extensive field visits by experts and interviews with the local farmers. A model prediction can have advantages over the field identification with respect to the consistency of the CSA identification in a larger area and time demand.

Several studies have been carried out to predict CSAs for different substances (nutrients, pesticides and sediment) on field and catchment scale (e.g. Srinivasan and McDowell, 2009; Lyon et al., 2006; Heathwaite et al., 2005; Agnew et al., 2006; Easton et al., 2008) with a variety of different modeling approaches (see Borah and Bera, 2003, for review on model concepts for diffuse pollution). Process-based models were found to be more suitable for CSA prediction by Srinivasan and McDowell (2009).

If the source areas of pollutants are known based on spatial crop information, the prediction of CSAs reduces to a purely hydrological problem where hydrologically active areas (Ambroise, 2004) and their connectivity to the stream have to be identified. In this paper we focus on the prediction of areas that can become saturated and produce saturationexcess overland flow because of high groundwater levels. Previous studies have demonstrated the relevance of this process for herbicide transport under conditions prevailing in the Swiss Plateau (Leu et al., 2004a). In contrast to areas where infiltration-excess overland flow occurs, the locations of saturation-excess overland flow areas on agricultural fields are temporally more stable across rainfall events of similar magnitude. This is because saturation excess areas on agricultural fields do not strongly depend on land management and soil coverage. They are influenced more by topographic position and hydrological subsoil properties (Lyon et al., 2006; Gerits et al., 1990; Doppler et al., 2012).

A main problem with the prediction of CSAs is the lack of spatial data on hydrological state variables. Predicting hydrological conditions that generate CSAs would require a physically based, fully distributed, integrated surface-subsurface model of catchment hydrology. Such models - like SHE (Abbott et al., 1986) and its derivatives or HydroGeoSphere
(Brunner and Simmons, 2012) - could theoretically be applied without calibration given full catchment information. However, since it is not possible to get full spatial information on catchment structure and status and because there are still considerable knowledge gaps (Refsgaard et al., 2010), spatially distributed models are often calibrated on aggregate data (like discharge measurements at specific locations) (Frey et al., 2011). However, the model parameters and even the model structure are only poorly identifiable when no spatial data are used for calibration (Grayson et al., 1992a, b). For several versions of the semi-distributed TOPMODEL it was shown that especially the transmissivity parameter can be better identified if spatial data on groundwater levels or saturated areas were included for calibration (Franks et al., 1998; Lamb et al., 1998; Freer et al., 2004; Blazkova et al., 2002; Gallart et al., 2007).

Soil maps are spatial databases that exist for many locations. Besides soil texture information, qualitative information on soil types can be used too in the context of hydrological models. Hrachowitz et al. (2013) state that hydrologically meaningful soil classification schemes are valuable for hydrological modeling (see e.g. Lazzarotto et al., 2006; Hahn et al., 2013). Boorman et al. (1995) developed the system of Hydrology Of Soil Types (HOST) where soils in the UK are classified according to a conceptual understanding of the water movement in these soils. It was shown that the HOST soil classes are related to the base flow index (the proportion of base flow on total stream flow) and can be used to support model parameterization (Dunn and Lilly, 2001). This system was successfully implemented in a hydrological model (Maréchal and Holman, 2005). The HOST system has also proven to be useful for a hydrological soil classification at European scale (Schneider et al., 2007). In addition to the development of conceptual hydrological understanding, as it was done in HOST, soil morphology information was also used to critically evaluate spatial model predictions. For example Güntner et al. (2004) used soil morphological and geobotanical criteria to delineate saturated areas in a mesoscale catchment to evaluate the predictions by different terrain indices.

Despite these efforts to make use of available spatial information, the general lack of available spatial data sets to calibrate and/or validate models that predict CSAs still persists (Srinivasan and McDowell, 2009; Easton et al., 2008; Frey et al., 2011). For the prediction of CSAs this is critical since the goal is to predict locations where certain hydrological processes occur. Meaningful model calibration and validation is a prerequisite if management decisions are to be based on the predicted CSAs .

We present an approach where we used two sources of spatial information. First, we used piezometric measurements at different locations in the study catchment for the joint calibration to observed discharge resulting in a multi-variable, multi-site objective function (Madsen, 2003). While such multi-objective calibration offers benefits for achieving a 
better representation of the internal state variables - e.g., spatial patterns of water saturation or saturated areas - it makes the calibration process more complex (Efstratiadis and Koutsoyiannis, 2010). Because of structural model errors, trade-offs among the different elements of the objective function emerge requiring subjective decisions about how to weigh different variables for example (Reichert and Schuwirth, 2012; Gupta et al., 1998). Here, we use a simple aggregation function (Efstratiadis and Koutsoyiannis, 2010) for combining the different state variables into a single objective function. These aspects will be further dealt with in the discussion.

Subsequently, we profited from soil morphology information from a traditional soil map to derive estimates of the average duration of soil saturation at a given depth. The resulting data set can then be used as model validation data. The rationale behind this approach is the fact that groundwater influences morphological features that are related to changing oxygen availability due to permanent water logging or fluctuating groundwater levels. These hydromorphic features are usually related to redox reactions and transport of iron and manganese (see e.g. Terribile et al., 2011). Accordingly, soil morphology as described in soil maps contains information on the soil water regime. Several studies have shown a relationship between soil morphology (especially soil matrix color and the presence and type of iron mottles) and the frequency of soil saturation (Simonson and Boersma, 1972; Jacobs et al., 2002; Morgan and Stolt, 2006; Franzmeier et al., 1983). To our knowledge, these morphological features have only been interpreted as binary information (saturated area or not saturated area) (Güntner et al., 2004) but not as quantitative estimates (frequency of soil saturation) for modeling purposes. To do so, one has to be aware of possible pitfalls related to a quantitative interpretation of soil morphology. These features depend on various factors like the composition of the parent material (Evans and Franzmeier, 1986; Franzmeier et al., 1983), soil texture (Jacobs et al., 2002; Morgan and Stolt, 2006) and soil chemistry (Terribile et al., 2011; Vepraskas and Wilding, 1983). Also, artificial drainage can influence soil morphology within decades (Montagne et al., 2009; Hayes and Vepraskas, 2000). We have tried to account for these uncertainties by the extensive field experience for soil mapping in this part of Switzerland by some of us (P. Weisskopf and U. Zihlmann). The resulting map of soil saturation durations itself could serve as proxy map for the identification of areas where saturation excess runoff occurs. However, in combination with a model, it could be used for a more detailed prediction with respect to the time of the year in which the saturation occurs or the amount of runoff produced on a certain area. Even if the resulting map of soil saturation frequencies remains uncertain to some degree, this additional information can reduce the uncertainty of model predictions (Franks et al., 1998).

If predicted CSAs should serve as basis for site specific pollution mitigation measures, they have to fulfill several criteria. They have to be reliable and the uncertainties have to be assessable. They should only be based on information that is generally available and the prediction algorithm has to be applicable to larger areas. At the same time the spatial resolution of prediction should be in the order of $10 \mathrm{~m} \times 10 \mathrm{~m}$ (or higher). Relevant transport processes for most pollutants except nitrate happen on the timescale of single events under the conditions prevailing in the study catchment. A temporal resolution in the order of hours is therefore required for a dynamic prediction model. These requirements cause a high computational demand. Furthermore, the desired accuracy for the prediction of the groundwater level is high. It needs to distinguish between areas that are often saturated to the surface and therefore produce surface runoff, and areas where the maximum groundwater level remains little below the surface.

In this paper we describe a case study where we applied a spatially distributed hydrological model for delineating CSAs that are caused by the generation of saturation-excess overland flow due to high groundwater levels. Similar to Frey et al. (2009) we chose to work with a process oriented model, which has the advantage that it is better transferable to other regions than models that rely on empirical relationships. The model was optimized for computational speed and mainly relies on generally available data so that it could be used for practical applications. As study site we selected a $1.2 \mathrm{~km}^{2}$ catchment in the Swiss Plateau, with a high variability of soil types and soil moisture regimes ranging from very wet to rather dry soils. One question we try to answer in this paper is if the spatial variability of depth to groundwater in this catchment can be explained only by topography and the presence of tile drains or if other factors like hydraulic soil properties are important driving factors in determining the groundwater levels. The frequency of soil saturation resulting from the quantitative interpretation of the soil map was not used for the model setup but only to critically evaluate the model predictions.

This case study therefore has the following main objectives:

1. We develop an approach to utilize more spatial information on soil water regimes. Soil morphological information was translated into spatially distributed data on water saturation as a function of soil depth in the study catchment. The result of this translation is a spatially distributed data set on the soil water regime which is based on generally available information.

2. We calibrate a parsimonious, distributed hydrological model for predicting CSAs to observed spatially distributed water table levels and discharge.

3. To validate the model performance, water level predictions are compared to the expected values derived from the soil map. 


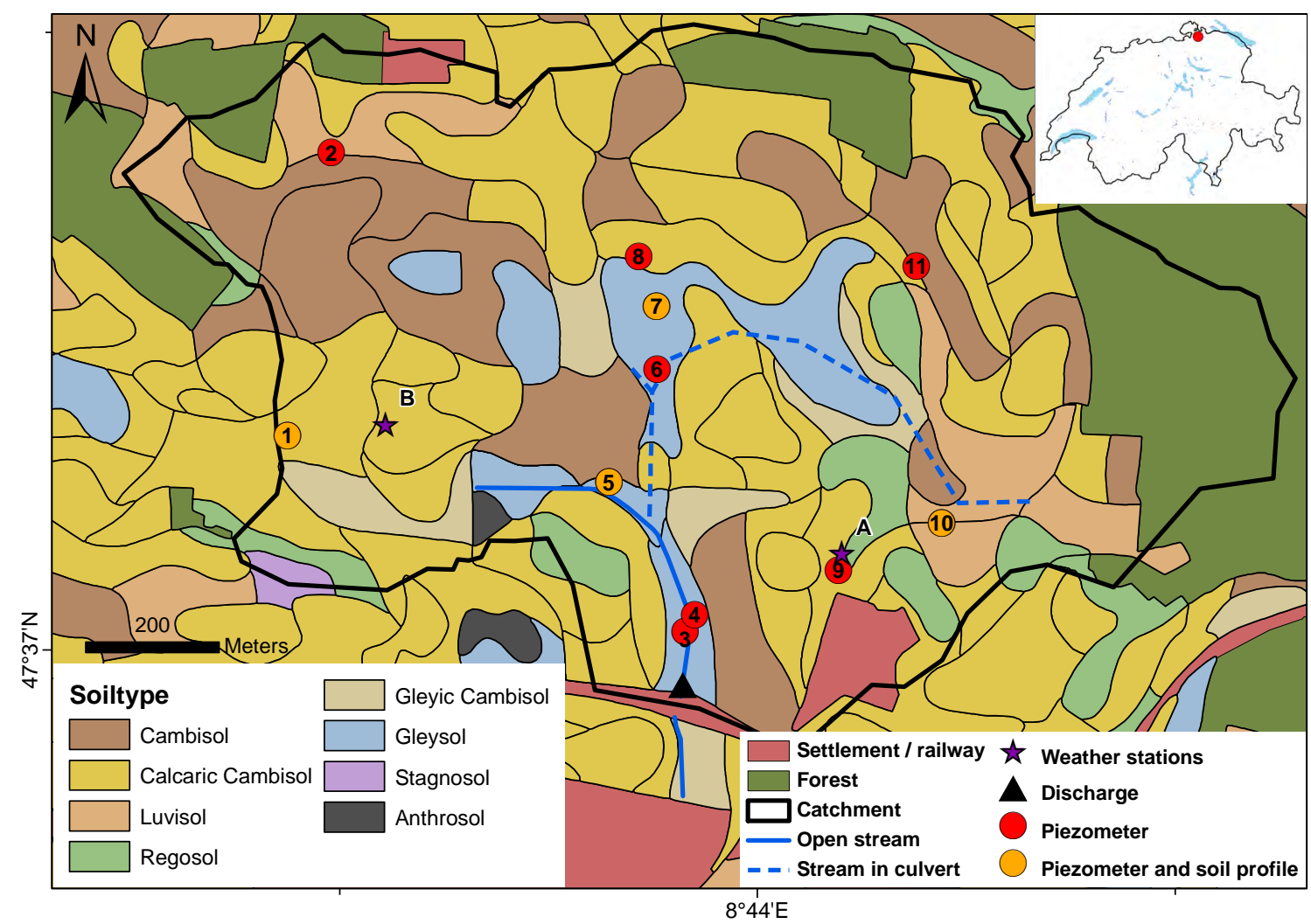

Figure 1. The experimental catchment with land use, soil types and the hydrological measurement locations. The small map in the top right corner depicts the location of the study site within Switzerland. Sources: swisstopo (2008); FAL (1997).

\section{Materials and methods}

\subsection{Site description}

The study catchment $\left(1.2 \mathrm{~km}^{2}\right)$ is located in the northeast of Switzerland (see Fig. 1). Topography is moderate with altitudes ranging from 423 to $477 \mathrm{~m}$ a.s.l. and an average slope of $4.3^{\circ}\left(\min =0^{\circ}, \max =42^{\circ}\right.$, based on $2 \mathrm{~m} \times 2 \mathrm{~m} \mathrm{dig}-$ ital elevation model (DEM), absolute accuracy: $\sigma=0.5 \mathrm{~m}$, resolution $=1 \mathrm{~cm}$, swisstopo, 2003). The 20-year mean annual precipitation at the closest permanent measurement station (Schaffhausen, $11 \mathrm{~km}$ north of the catchment) is $883 \mathrm{~mm}$ (MeteoSchweiz, 2009). The soils have developed on moraine material with a thickness of around 10 meters; underneath the moraine, we find fresh water molasse (Süsswassermolasse) (swisstopo, 2007; Einsele, 2000). Soils in the center of the catchment are poorly drained gleysols. In the higher parts of the catchment well drained cambisols and eroded regosols are found (FAL, 1997, see Fig. 1). Soil thickness (surface to $\mathrm{C}$ horizon) varies between $30 \mathrm{~cm}$ at the eroded locations and more than $2 \mathrm{~m}$ in the depressions and near the stream. The catchment is heavily modified by human activities; it encompasses a road network with a total length of $11.5 \mathrm{~km}$ (approximately $3 \mathrm{~km}$ are paved and drained, the rest is unpaved and not drained). The dominant land use is crop production ( $75 \%$ of the area), around $13 \%$ of the catchment is covered by forest, and a small settlement area is located in the southeast of the catchment. Three farms lie at least partly within the catchment (Fig. 1). $47 \%$ of the agricultural land is drained by tile drains with a total length of over $21 \mathrm{~km}$ (Gemeinde Ossingen, 1995), the open stream has a length of $550 \mathrm{~m}$. The main part of the drainage system was built in the 1930s. The stream system consists of two branches, an open ditch that was partly built as recipient for the drainage water, and the main branch of the stream that runs in a culvert (Fig. 1). The stream also receives the runoff from two main roads and from two farm yards (Gemeinde Ossingen, 2008). The paved area that drains into the catchment is approximately $1.5 \mathrm{ha}(1.2 \%$ of the area).

\subsection{Field measurements}

From 25 August 2008 to 14 October 2009, we monitored several hydrological variables in the catchment. We measured discharge at the outlet of the catchment (Fig. 1). Water level and flow velocity were measured using a Doppler probe and a pressure transducer (ISCO 750 area velocity flow module, Teledyne Inc., Los Angeles). Discharge was calculated using the exact cross section of the site. Discharge data were stored 
at 5-minute intervals by the data logger of an auto sampler (ISCO 6700, ISCO 6712, Teledyne Inc., Los Angeles, USA).

At weather station A (Fig. 1), precipitation was measured at $15 \mathrm{~min}$ resolution with a tipping bucket rain gauge (R102, Campbell Scientific, Inc., Loughborough, UK). This rain gauge was out of order for 22 days (4 June 200925 June 2009). During this time, rain data from weather station B (Fig. 1) were used (a mobile HP 100 Station run by Agroscope ART Reckenholz, $\mathrm{CH}$ with a tipping bucket rain gauge: HP 100, Lufft GmbH, Fellbach, DE). At weather station $\mathrm{A}$ we also recorded air temperature and relative humidity (Hygromer MP 100A, rotronic AG, Bassersdorf, CH), wind speed (A100R switching anemometer, Campbell Scientific, Inc., Loughborough UK), net radiation (Q-7 net radiometer, Campbell Scientific, Inc., Loughborough UK) and air pressure (Keller DCX-22, KELLER AG für Druckmesstechnik, Winterthur, $\mathrm{CH}$ ) in 15 min intervals. Daily reference evapotranspiration was calculated from the meteorological data after the Penman-Monteith equation (Allen et al., 1998). This results in the evapotranspiration of a reference grass surface without water limitation.

We installed 11 piezometers (Fig. 1) to monitor groundwater levels in 15 min intervals (STS DL/N, STS Sensor Technik Sirnach AG, Sirnach, CH and Keller DCX-22, KELLER AG für Druckmesstechnik, Winterthur, $\mathrm{CH}$ ). The installation depth varied between 1.5 and $2.7 \mathrm{~m}$ below the surface. At four of the piezometer locations, we additionally dug a $1.2 \mathrm{~m}$ deep soil pit (Fig. 1) to directly investigate hydromorphic features.

\subsection{GIS analysis}

The catchment boundary was calculated in ArcGIS (ESRI, ArcGIS Desktop, 9.3.1) based on the $2 \mathrm{~m} \times 2 \mathrm{~m}$ DEM (swisstopo, 2003) and manually adapted according to field observations, the detailed tile drain map (Gemeinde Ossingen, 1995) and the rain sewer map (Gemeinde Ossingen, 2008). The topographical catchment does not coincide completely with the subsurface catchment. In some areas that belong to the topographical catchment, the tile drains divert the water outside of the catchment. These areas were excluded. In contrast, the settlement area in the southeast was kept in the catchment, even though the water from sealed areas in the settlement leaves the catchment.

The original $2 \mathrm{~m} \times 2 \mathrm{~m}$ DEM (swisstopo, 2003) was used for the analysis of surface connectivity. Firstly, very small or shallow depressions were removed, as these can either be artifacts in the DEM or are too shallow to trap significant amounts of overland flow. Depressions consisting of one or two cells and those with a maximum depth of less than $5 \mathrm{~cm}$ were filled. All other depressions were kept. Secondly, the cells in the open stream were incised to the depth of the average water level. Depression analysis and filling as well as stream incision were performed in TAS (Terrain Analysis System, geographical information system version 2.0.9,
John Lindsey 2005). Based on this corrected DEM, flow directions and flow accumulation were calculated in ArcGIS. The lowest stream channel cell was used as pour point for the catchment calculation to determine the area connected directly to the stream on the surface.

The corrected DEM was also used as surface topography in the model. The topographic wetness index (Beven and Kirkby, 1979) (Eq. 1) was calculated with the multiple-flowdirection algorithm $D_{\text {inf }}$ (Tarboton, 1997) implemented in TAS, based on the corrected DEM.

$\lambda=\ln \left(\frac{A}{\tan (\beta)}\right)$

$\lambda$ is the topographic wetness index, $A$ the upslope area and $\beta$ is the local slope.

\subsection{Soil map translation}

We worked with the 1 : 5000 soil map of Canton Zurich (FAL, 1997). The soil map classifies agricultural soils after the Swiss soil classification system (FAL, 1997); forest soils are not classified. The soils are characterized according to their physical, chemical and morphological properties. For the estimation of the duration of soil saturation, the soil units (Fig. 1) were grouped into seven water regime classes, according to their expected water regime. For each of these classes we estimated how long it is saturated in six different depths $(5,30,50,75,105,135 \mathrm{~cm})$. We used the following morphological redox features to estimate the duration of soil saturation within a soil horizon: (i) the presence and abundance of manganese concretions in the horizon, (ii) the presence and abundance of iron mottles, (iii) the presence of iron mottles together with pale soil matrix, and (iv) fully reduced horizons. These features of the horizons were interpreted within the context of the respective soil profile and the expected water regime of the soil water regime class. Since variations are expected within the classes and because the estimation itself is uncertain, we additionally estimated a range of soil saturation in which we expect two thirds of the soils that are classified in the respective class.

\subsection{Model description}

\subsubsection{Model concept}

The model we worked with has a conceptual representation of the unsaturated zone and a spatially distributed, more process-based representation of the saturated zone. Under wet temperate climate lateral flow in the saturated zone is an important process to determine the shape of the groundwater table in shallow groundwaters and therefore the prediction of saturated areas. For the saturated zone we chose an approach similar to HillVI (Weiler and McDonnell, 2004) where the groundwater level gradients are calculated in each time step and do not rely on surface topography. This should result in 
more realistic predictions of the location of saturated areas (Grabs et al., 2009). We additionally implemented the lateral and preferential flow to tile drains. These are important processes because large parts of the crop production areas in Switzerland are artificially drained.

The model simulates water fluxes in a catchment. It is based on the following water balance equation:

$\frac{\mathrm{d} S}{\mathrm{~d} t}=P-\mathrm{ET}-Q$,

with $S[\mathrm{~L}]$ being the total water storage in the catchment, $P\left[\mathrm{~L} \mathrm{~T}^{-1}\right]$ is precipitation, ET $\left[\mathrm{L} \mathrm{T}^{-1}\right]$ is evapotranspiration and $Q\left[\mathrm{~L} \mathrm{~T}^{-1}\right]$ is stream discharge. We do not consider subsurface in- or outflow. The calculations were optimized for computational speed.

The model consists of three separate, linked modules (Fig. 2):

1. The paved area module is a lumped and conceptual model that calculates runoff and evaporation from paved areas.

2. The unsaturated zone module calculates recharge from the unsaturated zone to the saturated zone, preferential flow that bypasses the unsaturated zone and directly enters the saturated zone, and evapotranspiration from the unsaturated zone. It is possible to have several unsaturated zone modules (e.g., one for each soil type), each of which recharges into different sections of the saturated zone module.

3. The saturated zone module is spatially distributed (grid cells) and more process-based. It simulates lateral groundwater flow, drain flow, evapotranspiration from the saturated zone, and saturation-excess overland flow. The concept of the saturated zone module was inspired by HillVi (Weiler and McDonnell, 2004).

The modeled stream discharge consists of the following components:

$Q=Q_{\text {paved }}+Q_{\text {surf }}+D_{\text {lat }}+D_{\text {pref }}$,

where $Q_{\text {paved }}\left[\mathrm{L} \mathrm{T}^{-1}\right]$ is runoff from the paved area, $Q_{\text {surf }}$ $\left[\mathrm{L} \mathrm{T}^{-1}\right]$ is saturation excess surface runoff (this term also comprises lateral groundwater flow to the stream, see below), $D_{\text {lat }}\left[\mathrm{L} \mathrm{T}^{-1}\right]$ is lateral drain flow, and $D_{\text {pref }}\left[\mathrm{L} \mathrm{T}^{-1}\right]$ is preferential drain flow.

The modeled evapotranspiration is calculated as follows:

$\mathrm{ET}=E_{\text {paved }}+\mathrm{ET}_{\text {uns }}+\mathrm{ET}_{\text {sat }}$,

where $E_{\mathrm{paved}}\left[\mathrm{L} \mathrm{T}^{-1}\right]$ is the evaporation from paved areas, $\mathrm{ET}_{\text {uns }}\left[\mathrm{L} \mathrm{T}^{-1}\right]$ is the evapotranspiration from the unsaturated zone, and $\mathrm{ET}_{\text {sat }}\left[\mathrm{L} \mathrm{T}^{-1}\right]$ is the evapotranspiration from the saturated layer. In the following the three modules are described in detail.

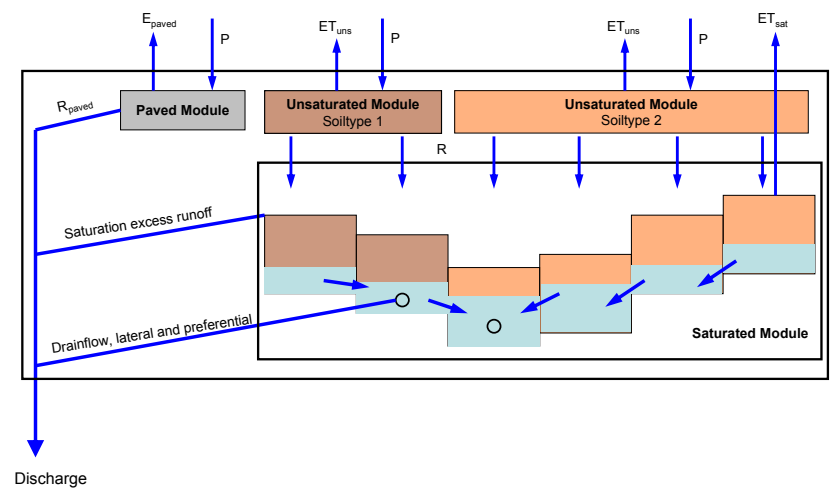

Figure 2. Schematic picture of the model concept.

\section{Paved area module}

The change in the paved storage is modeled as follows:

$\frac{\mathrm{d} S_{\text {paved }}}{\mathrm{d} t}=P-E_{\text {paved }}-Q_{\text {paved }}$,

with $S_{\text {paved }}$ [L] being the paved storage.

Runoff from paved areas linearly depends on the paved storage.

$$
\begin{aligned}
& Q_{\text {paved }}= \\
& \begin{cases}0 & \text { if } S_{\text {paved }} \leq S_{\text {paved_min }} \\
\left(S_{\text {paved }}-S_{\text {paved_min }}\right) k_{\text {paved }} & \text { if } S_{\text {paved }}>S_{\text {paved_min }}\end{cases}
\end{aligned}
$$

$S_{\text {paved_min }}[\mathrm{L}]$ is the minimum storage that has to be filled to produce runoff and $k_{\mathrm{paved}}\left[\mathrm{T}^{-1}\right]$ is the outflow rate.

If there is water in the paved storage, it can evaporate with the following rate

$E_{\text {paved }}=\mathrm{ET}_{\text {ref }} \cdot m_{\text {paved }}$,

where $\mathrm{ET}_{\text {ref }}\left[\mathrm{L} \mathrm{T}^{-1}\right]$ is the reference evapotranspiration calculated from meteorological data (see Sect. 2.2), and $m_{\text {paved }}$ $[-]$ is a multiplier.

\section{Unsaturated zone module}

The water balance of the unsaturated zone is represented as follows:

$\frac{\mathrm{d} S_{\mathrm{uns}}}{\mathrm{d} t}=P-\mathrm{ET}_{\mathrm{uns}}-R$,

where $S_{\mathrm{uns}}[\mathrm{L}]$ is the unsaturated storage, and $R\left[\mathrm{~L} \mathrm{~T}^{-1}\right]$ is recharge to the saturated zone. $R$ consists of a slow recharge component $\left(R_{\text {slow }}\right)$ and preferential flow $\left(R_{\text {pref }}\right)$.

$R=R_{\text {slow }}+R_{\text {pref }}$

$R_{\text {slow }}$ linearly depends on the storage amount above field capacity. If the unsaturated storage is below field capacity, 
$R_{\text {slow }}$ is assumed to be zero.

$R_{\text {slow }}= \begin{cases}0 & \text { if } S_{\mathrm{uns}}<S_{\mathrm{fc}} \\ \left(S_{\mathrm{uns}}-S_{\mathrm{fc}}\right) k_{\mathrm{uns}} & \text { if } S_{\mathrm{uns}} \geq S_{\mathrm{fc}}\end{cases}$

$S_{\mathrm{fc}}[\mathrm{L}]$ is the unsaturated store at field capacity and $k_{\mathrm{uns}}\left[\mathrm{T}^{-1}\right]$ is the outflow rate.

A part of the precipitation bypasses the unsaturated zone as preferential flow and directly enters the saturated zone. This only occurs if the unsaturated zone is above field capacity, and it exponentially depends on the water content in the unsaturated zone.

$R_{\text {pref }}= \begin{cases}0 & \text { if } S_{\mathrm{uns}}<S_{\mathrm{fc}} \\ k_{\text {pref }}\left(\frac{S_{\mathrm{uns}-}-S_{\mathrm{fc}}}{S_{\mathrm{uns} \_ \text {max }}-S_{\mathrm{fc}}}\right)^{e_{\mathrm{pref}}} \cdot P & \text { if } S_{\mathrm{uns}} \geq S_{\mathrm{fc}}\end{cases}$

$k_{\text {pref }}[-]$ and $e_{\text {pref }}[-]$ are empirical parameters.

Above field capacity the evapotranspiration from the unsaturated module is at maximum, below field capacity it is reduced. The reference evapotranspiration calculated from meteorological data $\left(\mathrm{ET}_{\text {ref }}\right)$ refers to a reference grass surface. A time dependent multiplier $\left(m_{\mathrm{uns}}\right)$ was introduced to account for crops with different water requirements and the time dependence of the leaf area index (LAI) due to crop development.

$$
\begin{aligned}
& \mathrm{ET}_{\mathrm{uns}}= \\
& \begin{cases}\mathrm{ET}_{\mathrm{ref}} \cdot m_{\mathrm{uns}} & \text { if } S_{\mathrm{uns}} \geq S_{\mathrm{fc}} \\
\mathrm{ET}_{\mathrm{ref}} \cdot m_{\mathrm{uns}}\left(\frac{\frac{S_{\mathrm{uns}}}{S_{\mathrm{fc}}}}{\frac{S_{\mathrm{uns}}}{S_{\mathrm{fc}}}+k_{\mathrm{et}}}\right)\left(1+k_{\mathrm{et}}\right) & \text { if } S_{\mathrm{uns}}<S_{\mathrm{fc}}\end{cases}
\end{aligned}
$$

with $k_{\text {et }}[-]$ and $m_{\text {uns }}$ [-] being parameters. The change of the LAI is coupled to air temperature and incorporated in the time dependent parameter $m_{\mathrm{uns}}$.

$$
\begin{aligned}
& \frac{\mathrm{d} m_{\mathrm{uns}}}{\mathrm{d} t}= \\
& \begin{cases}m_{\mathrm{uns}} \cdot \mu_{0}\left(T_{\mathrm{air}}-T_{0}\right)\left(1-\frac{m_{\mathrm{uns}}}{m_{\mathrm{uns}, \max }}\right) & \text { if } T_{\mathrm{air}} \geq T_{0} \\
m_{\mathrm{uns}} \cdot k_{\mathrm{decay}}\left(T_{\mathrm{air}}-T_{0}\right) & \text { if } T_{\text {air }}<T_{0} \\
0 & \text { if } m_{\mathrm{uns}} \leq m_{\mathrm{uns}, \min }\end{cases}
\end{aligned}
$$

where $\mu_{0}\left[\mathrm{~T}^{-1} \mathrm{Te}^{-1}\right]$ and $k_{\text {decay }}\left[\mathrm{T}^{-1} \mathrm{Te}^{-1}\right]$ are parameters, $T_{\text {air }}$ [Te] is air temperature, $T_{0}[\mathrm{Te}]$ is the minimum temperature above which LAI starts increasing, $m_{\text {uns, min }}[-]$ and $m_{\mathrm{uns}, \max }[-]$ are the minimum and maximum values for $m_{\mathrm{uns}}$.

\section{Saturated zone module}

The saturated module is spatially distributed. The water balance within a grid-cell is calculated as follows:

$$
\frac{\mathrm{d} S_{\mathrm{sat}}}{\mathrm{d} t}=R-\mathrm{ET}_{\mathrm{sat}}+\mathrm{SF}_{\mathrm{lat}}-i \cdot D_{\text {lat }}-i \cdot D_{\text {pref }}-j \cdot Q_{\mathrm{surf}},
$$

where $S_{\text {sat }}[\mathrm{L}]$ is the storage in the cell and $\mathrm{SF}_{\text {lat }}\left[\mathrm{L} \mathrm{T}^{-1}\right]$ is the lateral groundwater flow between cells.

$i= \begin{cases}1 & \text { for drained cells } \\ 0 & \text { for undrained cells }\end{cases}$

$j= \begin{cases}1 & \text { for cells with surface connectivity to the } \\ & \text { stream, see Sect. } 2.3 \\ 0 & \begin{array}{l}\text { for cells without surface connectivity } \\ \text { to the stream }\end{array}\end{cases}$

The change of the groundwater level in the cell is therefore calculated as follows

$\frac{\mathrm{d} h}{\mathrm{~d} t}=\frac{\frac{d S_{\mathrm{sat}}}{\mathrm{d} t}}{p_{\mathrm{eff}}}$

where $h[\mathrm{~L}]$ is the groundwater level and $p_{\text {eff }}[-]$ is the effective porosity.

If the unsaturated zone is below field capacity and evapotranspiration from the unsaturated zone is therefore reduced, evapotranspiration can occur directly from the saturated zone.

$\mathrm{ET}_{\mathrm{sat}}= \begin{cases}0 & \text { if } S_{\mathrm{uns}} \geq S_{\mathrm{fc}} \\ m_{\mathrm{sat}}\left(\mathrm{ET}_{\mathrm{ref}} \cdot m_{\mathrm{uns}}-\mathrm{ET}_{\mathrm{uns}}\right) & \text { if } S_{\mathrm{uns}}<S_{\mathrm{fc}}\end{cases}$

At maximum, $\mathrm{ET}_{\mathrm{sat}}$ accounts for the evapotranspiration deficit in the unsaturated zone, the multiplier $m_{\text {sat }}[-]$ is between 0 and 1 .

The lateral groundwater flow between cells is calculated based on the Dupuit-Forchheimer assumption. We furthermore assume isotropy in $K_{\text {sat }}$ :

$q_{\text {lat }}=K_{\text {sat }} \cdot \nabla h$,

where $q_{\text {lat }}\left[\mathrm{L} \mathrm{T}^{-1}\right]$ is the flux density, $K_{\text {sat }}\left[\mathrm{L} \mathrm{T}^{-1}\right]$ is the saturated hydraulic conductivity, and $h[\mathrm{~L}]$ is the groundwater head. The water flow between two neighboring cells can then be calculated as follows:

$Q_{\text {lat }}=K_{\text {sat }} \cdot M_{\text {sat }} \cdot L_{\text {cell }} \frac{\Delta h}{L_{\text {cell }}}$,

where $Q_{\text {lat }}\left[\mathrm{L}^{3} \mathrm{~T}^{-1}\right]$ is the water flow between two cells, $M_{\text {sat }}$ [L] is the thickness of the saturated layer, and $L_{\text {cell }}[\mathrm{L}]$ is the cell length. If we sum up the water flows to and from all neighboring cells and divide the sum by the cell area, we receive $\mathrm{SF}_{\text {lat }}$.

In drained cells, the lateral groundwater flow into the drain is calculated based on the Hooghoudt equation as described by Beers (1976). We used an equation modified from Wittmer (2010) because the distance to single tiles is not considered explicitly. The flow depends on the water level above the drains.

$D_{\text {lat }}=4 r_{\mathrm{dr}} \cdot K_{\mathrm{sat}}\left(\frac{m_{\mathrm{dr}} \cdot H_{\mathrm{dr}}}{\mathrm{Sp}_{\mathrm{dr}}}\right)^{2}$ 
$D_{\text {lat }}\left[\mathrm{L} \mathrm{T}^{-1}\right]$ is the drain flow, $r_{\mathrm{dr}}[-]$ is a parameter that determines the entrance resistance to the tile drains, $m_{\mathrm{dr}}[-]$ is a multiplier to obtain the water level in the middle between two drains from the modeled water level in the cell, $H_{\mathrm{dr}}[\mathrm{L}]$ is the water table height above the drain, and $\mathrm{Sp}_{\mathrm{dr}}[\mathrm{L}]$ is the drain spacing.

If the groundwater level reaches the surface in a cell, three cases are distinguished:

1. The cell is directly connected to the stream on the surface (see Sect. 2.3). In this case all water above the surface is directly added to discharge ( $\left.Q_{\text {surf }}\right)$.

2. The cell is not connected but it is drained. In this case, all water above the surface is added to drain flow as preferential flow ( $\left.D_{\text {pref }}\right)$.

3. The cell is neither connected to the stream nor drained. The water remains in the cell.

The coupling between the saturated zone module and the unsaturated zone module is unidirectional from the unsaturated zone to the saturated zone. The fact that a cell is saturated to the surface does not influence the unsaturated zone module above it. It is possible that the unsaturated zone above a saturated cell is not completely full. This concept was chosen to achieve a high computational efficiency.

The stream channel cells are incised to a mean water level in the stream. The surface topography in the stream cells is therefore represented by the mean water level and all the water above this level in the cell is directly converted to discharge. Lateral groundwater flow to stream cells is therefore also converted to $Q_{\text {surf }}$.

\subsubsection{Model setup}

We ran the model with homogeneous hydraulic properties in the saturated zone; only topography and the presence of tile drains were spatially distributed. The unsaturated zone was divided into several classes according to land use (forest, settlement, agriculture) and, within agricultural land use, according to the seven soil categories (see Sect. 2.4). We therefore ended up with nine unsaturated zone classes (forest, settlement and the seven soil categories). The reason for this setup was the assumption that the groundwater level in the catchment is mainly influenced by topography and artificial drainage and not by hydraulic soil properties (soil texture is rather homogeneous within the catchment, FAL, 1997). However, to account for the spatial distribution of the unsaturated zone thickness (which also influences the other parameters of the unsaturated zone module), we divided the unsaturated zone into classes according to their soil water regime. The classification of soil water regimes was only used for the spatial division of the unsaturated zone (but not its parameterization).

The saturated zone was represented by a $16 \mathrm{~m} \times 16 \mathrm{~m}$ grid; the cells were $10 \mathrm{~m}$ thick. We assume that the soil and the moraine are the conducting layers while the Fresh water molasse is assumed to be impermeable (see Sect. 2.1). The calculations were run with hourly input time series; the model output was also in hourly steps.

\subsubsection{Implementation}

The model equations were implemented in a $\mathrm{C}++$ program to achieve fast model simulations. The ordinary differential equations of the conceptual unsaturated zone modules and the paved area module were numerically integrated with the LSODA solver package (Livermore Solver for Ordinary Differential Equations, Hindmarsh, 1983; Petzold, 1983). The partial differential equations of the saturated zone module were integrated with an explicit Euler solution scheme with a computational time step $(20 \mathrm{~min})$ that guaranteed numerical stability during the simulation period. The integration of the saturated zone module was sped up by parallelizing the explicit solution scheme with OpenMP threads (for the specification see http://openmp.org). Despite all these efforts the simulation of the 2-D groundwater surface remained rather time consuming requiring $28 \mathrm{~s}$ of computation time for $1 \mathrm{yr}$ of forward simulation on an Intel Core i7-3960X CPU (3.3 GHz).

Model implementation and model setup (e.g., spatial and temporal resolution) were chosen in a way that guaranteed simulations fast enough to allow a possible use for practical applications.

\subsubsection{Calibration}

The model was simultaneously calibrated to the discharge time series and the groundwater level time series in the eleven piezometers. A maximum likelihood approach was used. Discharge was Box-Cox transformed before calibration with $\lambda=1 / 3$ (Box and Cox, 1964, 1982). The transformation equation was as follows:

$g(x)=\frac{x^{\lambda}-1}{\lambda}$

This was done to reduce heteroscedasticity of discharge errors. We assumed independent and normally distributed errors for the transformed discharge and the (untransformed) groundwater levels; the individual standard deviations for these were also calibrated. The likelihood function therefore looked as follows:

$$
\begin{aligned}
& L(\boldsymbol{\theta}, \boldsymbol{\sigma}) \propto \prod_{i=1}^{11} \prod_{j=1}^{m} \frac{1}{\sigma_{i} \sqrt{2 \pi}} \exp \left(-\frac{1}{2}\left(\frac{O_{i}^{j}-M_{i}^{j}(\boldsymbol{\theta})}{\sigma_{i}}\right)^{2}\right) \\
& \times \prod_{j=1}^{m} \frac{1}{\sigma_{\mathrm{d}} \sqrt{2 \pi}} \exp \left(-\frac{1}{2}\left(\frac{g\left(O_{\mathrm{d}}^{j}\right)-g\left(M_{\mathrm{d}}^{j}(\boldsymbol{\theta})\right)}{\sigma_{\mathrm{d}}}\right)^{2}\right),
\end{aligned}
$$

where $L$ is the likelihood, $\boldsymbol{\theta}$ is the vector of model parameters, $\sigma$ is the vector of the standard deviations, $i$ are the 
11 piezometer locations, $j$ are the time points, $\sigma_{i}$ is the standard deviation at piezometer $i, O_{i}^{j}$ is the observed groundwater level at piezometer $i$ and time $j, M_{i}^{j}(\boldsymbol{\theta})$ is the modeled groundwater level at piezometer $i$ and time $j, \sigma_{\mathrm{d}}$ is the standard deviation of the transformed discharge, $g(x)$ is the Box-Cox transformation (Eq. 22), and $O_{\mathrm{d}}^{j}$ is the observed discharge at time $j$ and $M_{\mathrm{d}}^{j}(\boldsymbol{\theta})$ is the modeled discharge at time $j$.

When calibrating a grid cell model to piezometer measurements, one has to be aware of the difference in spatial support. The model cell represents an area of $16 \mathrm{~m} \times 16 \mathrm{~m}$ while the piezometers are point measurements. The spatial variability of groundwater levels within each model cell can therefore be considerable (see e.g., Freer et al., 2004) and this variability cannot be resolved by the model. This is especially true for drained areas, where the tile drains increase the spatial variability of groundwater levels.

In the context of multi-objective calibration our approach corresponds to a simple aggregation function (Efstratiadis and Koutsoyiannis, 2010) for combining the different state variables into a single objective function where the tradeoffs between the different objectives are not made explicit. The weighting of the different state variables in the objective function was done by using individual error variances for each state variable (Reichert and Schuwirth, 2012). These error variances were also calibrated as parameters within the optimization. Hence, the optimization algorithm was allowed to choose the weighting that has the maximum likelihood. Implications of this approach will be discussed in the discussion section.

During calibration the likelihood function was optimized with a coupled global-local algorithm. Optimization started with the Particle Swarm algorithm (Kennedy and Eberhart, 1995) and after reaching the stop criterion NelderMead Simplex optimization (Nelder and Mead, 1965) was launched from the best parameter combination.

We chose a period in spring and summer 2009 as calibration period. It starts very wet in the beginning of spring, includes a long dry period, several rain events with varying magnitudes and intensities and it also contains the largest discharge event in the measurement period. We do not have continuous measurement time series from all the piezometers. For each piezometer we chose the calibration period so, that all the calibration time series (discharge and the 11 piezometers) contained the same number of observations. With this, the weighting of the different state variables within the objective function only depends on their error variance and not implicitly on the number of observations used for calibration. For piezometers 10 and 11 no data were available in the later period, so their calibration period is partially within the warm up phase of the model. Even though this might be problematic because we calibrate the model in a state where it is not yet completely adapted to the parameter set, we kept these two piezometers in the calibration. The main reason for this was that they are the two piezometers with the lowest groundwater levels and are therefore important for a complete spatial picture of the groundwater surface in the catchment. This more complete spatial picture was of greater importance to us than the potentially problematic calibration in the model warm up period.

Most of the model parameters were calibrated to achieve the best possible model output with the given model structure. (The Tables S1 to S4 in the Supplement indicate which of the parameters were calibrated and which were kept fixed during calibration. The tables also indicate the minimum and maximum values that were allowed in the calibration.) The initial state of the unsaturated zone was calibrated as well. The initial condition for the groundwater level is difficult to calibrate because the shape of the surface depends on the model parameters. The model run was started 5 months before the calibration period to adapt the groundwater surface to the model parameters. Additionally, we added a parameter that allows a homogeneous shifting up or down of the groundwater initial state and chose an adaptive procedure. After a first calibration, we used a groundwater level map from the optimum parameter set as initial condition for a second calibration. In a first step we calibrated a model version with a homogeneous unsaturated zone. From the resulting optimum parameter set, we launched the calibration of the model version with the spatially distributed unsaturated zone. With this setup, one full optimization (global and local) took about 1 week, depending on the speed of convergence.

\section{Results}

\subsection{Saturation estimates}

Figure 3a shows the map of the seven water regime classes from the reclassification of the soil map. Class 1 is the driest, class 7 the wettest water regime class. In Fig. 4 the estimated saturation durations in the water regime classes are shown. To evaluate the map-based estimates of the water regime we can compare the estimates with the measured groundwater levels from the piezometers (Fig. 4). In general, the estimated durations of soil saturation are in good agreement with the piezometers. There are some deviations at specific locations like the very wet piezometer in the driest soil class (piezometer 1 in Fig. 1 indicated by an arrow in Fig. 4). For a further evaluation of the spatial distribution of the water regime classes, we compared the water regime class map (Fig. 3a) with the topographic wetness index (Fig. 3b). The comparison reveals a generally good match between the two maps (high topoindex means wet soil). Even small scale features in the topoindex map are reflected in the soil map (e.g., in the $\mathrm{NE}$ of the catchment). For a quantitative comparison of the two maps, we classified the wettest two water regime classes (classes 6 and 7) as potential CSAs. This resulted in $20 \%$ of the area classified as CSA. For the topoindex map we also 

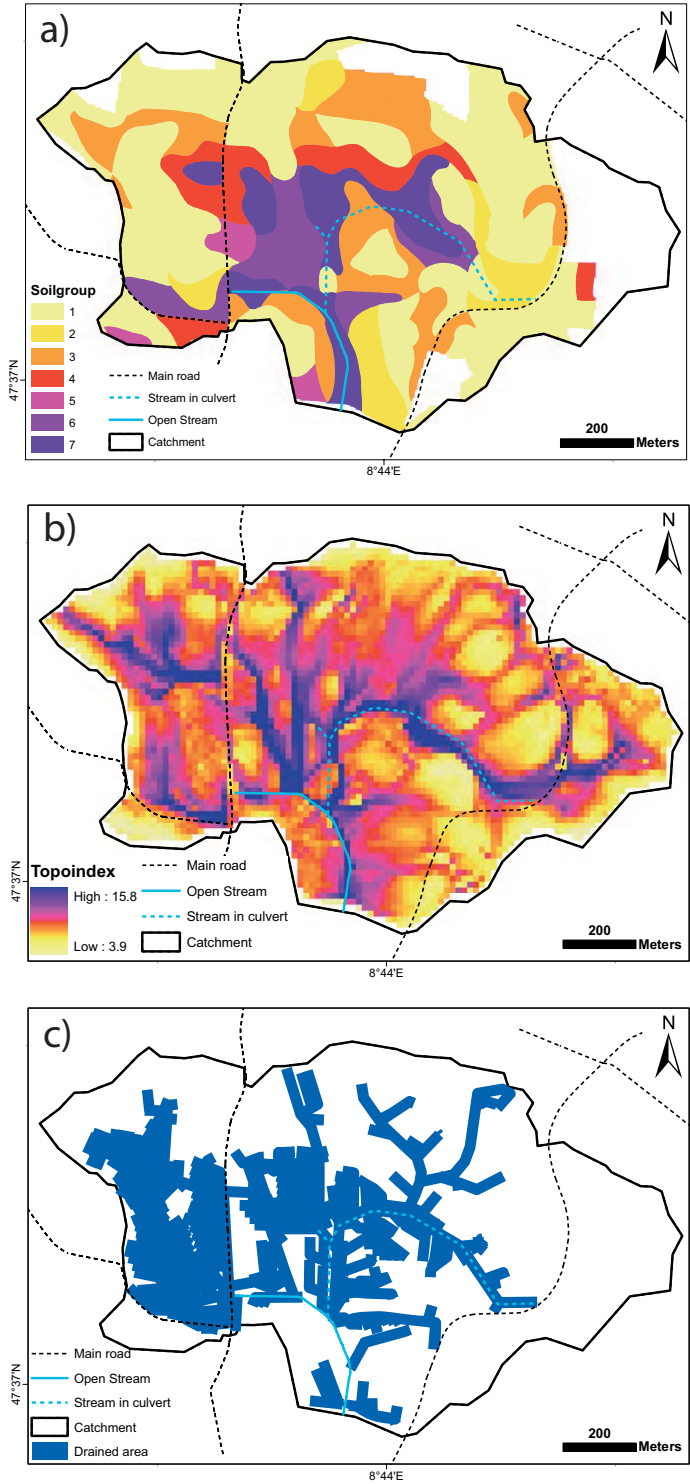

Figure 3. (a) The reclassified soil map with the seven soil water regime classes (class 1 is the driest, class 7 the wettest), (b) map of the topographic wetness index, (c) map of the drained areas in the catchment. Sources: Gemeinde Ossingen (1995); swisstopo (2008).

classified the wettest $20 \%$ as CSA. The areal overlap of the CSAs from the two methods is $52 \%$. Despite this reasonable agreement between the two maps there are some areas with rather high topoindices where the soils are classified in dry soil classes (e.g., in the west of the catchment).

The location of tile drains also contains information on the soil water regime. The tile drain map can therefore be used as additional comparison to verify the soil map estimates. Tile drains are only present at locations with excess groundwater that has to be diverted. Drained areas are therefore good indicators of originally higher groundwater levels. Because the drains are installed between 1 and $1.5 \mathrm{~m}$ below

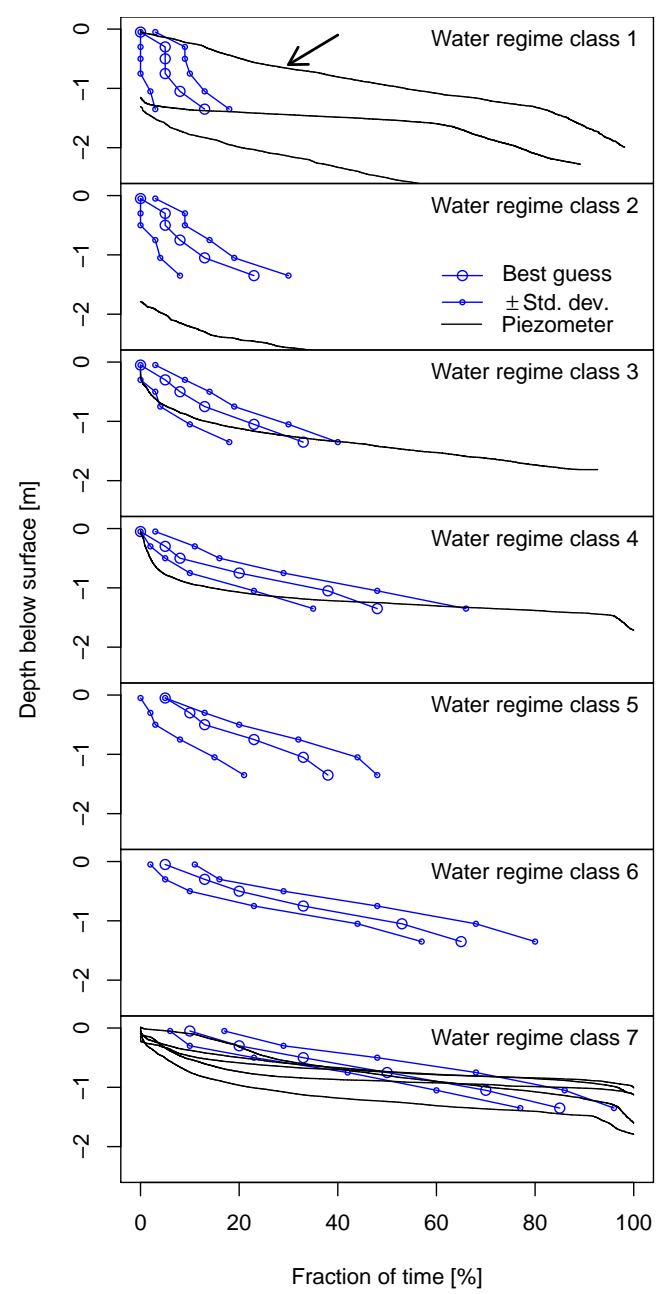

Figure 4. The estimated depth dependent saturation durations in the seven water regime classes with the expected variation within each class (blue) together with the measured saturation duration in the piezometers (black).

the surface in the study catchment, groundwater levels are still expected to be rather high in drained areas. We therefore used the drainage map (Fig. 3c) as a further evaluation of the map of soil water regime classes. The comparison reveals that drained areas are characterized by high topographic indices and that the drained soils are usually classified into a wet water regime class. However, the western part of the catchment is intensely drained and has rather high topographic wetness indices, but large areas are classified in the driest water regime class. Also the wet piezometer in water regime class 1 (Fig. 4, indicated by an arrow) is located in this area. The local assessment in the soil pit besides piezometer 1 (Fig. 1) supports the map-based estimate. Only few small iron mottles were found below $1 \mathrm{~m}$. The piezometric measurement therefore contradicts the local morphological interpretation in the soil pit and the map-based estimate. This is the only soil pit location where this is the case, in the 


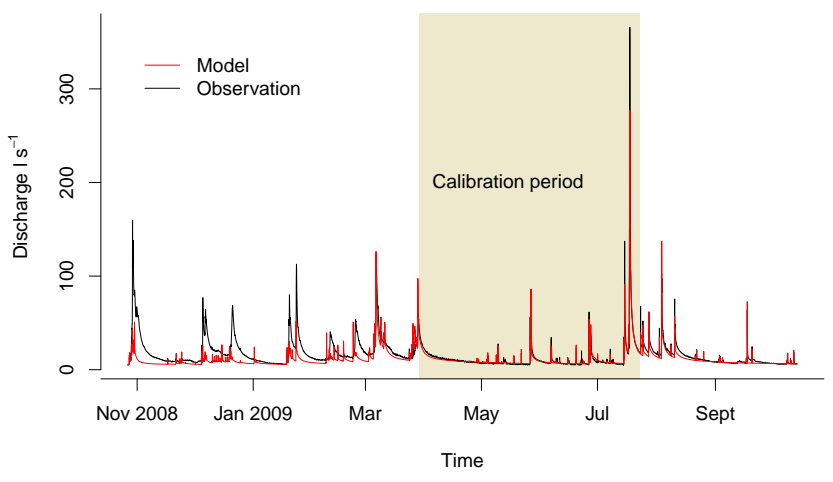

Figure 5. The modeled and measured discharge time series.

other three soil pits (Fig. 1) the piezometric measurement, the local morphological interpretation in the soil pit and the map-based estimate corresponded well.

\subsection{Calibration results and model validation}

After calibration (the optimum parameter set can be found in Tables S1 to S4 in the Supplement), the model performed satisfactory with respect to discharge and absolute groundwater levels. Figure 5 shows the predicted and measured discharge time series. The bad fit in the beginning stems from the difficulty to calibrate the initial groundwater level (see Sect. 2.5.4). After this initial phase, the discharge prediction is good with a Nash-Sutcliffe coefficient (Nash and Sutcliffe, 1970) of 0.91 for the calibration period. Also the predicted average groundwater levels at the piezometer locations are in good agreement with the measurements (Table 1). After the initial phase, the root mean square error (RMSE) of the groundwater level prediction ranged between $22 \mathrm{~cm}$ and $1 \mathrm{~m}$ with a median of $41 \mathrm{~cm}$ (Table 1). The model was therefore able to reproduce the general hydrological behavior of the catchment. The modeled composition of the discharge, with most of the discharge originating from the drainage system, was also in satisfactory agreement with the measurements: the model attributed $82 \%$ of total discharge to discharge from tile drains, while we estimate $62 \%$ based on the measurements.

However, if the time series of the groundwater levels are plotted as depth below the soil surface (Fig. 6) it becomes obvious that there is a lack of groundwater level dynamics in the model. The observed groundwater levels are much more dynamic than the modeled ones. Additionally, Fig. 6 shows that the depth to groundwater in the model prediction is rather homogeneous throughout the area. The modeled average depth to groundwater does not vary much between the piezometer locations. In contrast, the measured depth to groundwater is more variable.

To further investigate the model performance with respect to the spatial distribution of groundwater levels we used the estimated saturation durations from the soil map (Fig. 7).

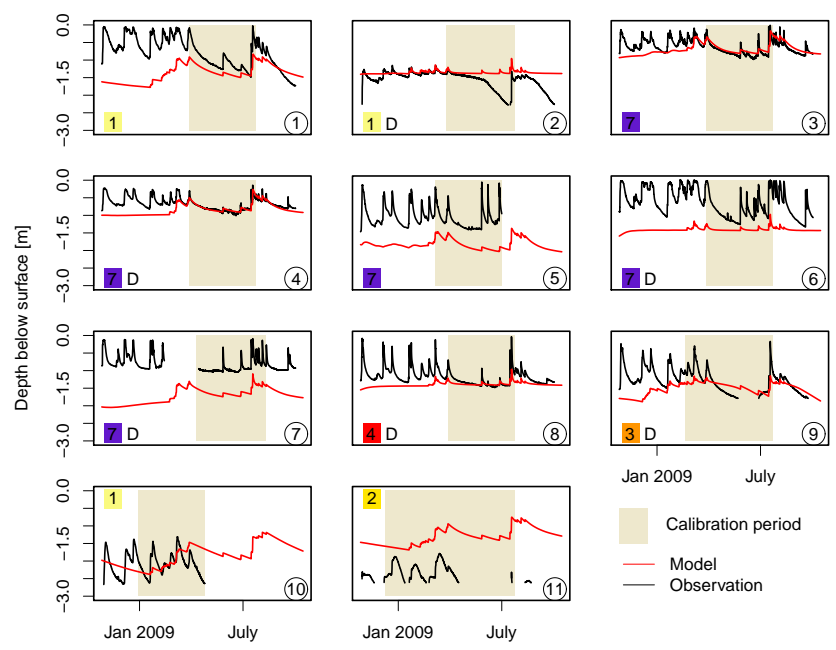

Figure 6. The modeled and measured groundwater levels at the piezometer locations as depth from the surface. The individual calibration periods are indicated (see Sect. 2.5.4). The circled number is the piezometer location (Fig. 1), the number in the colored box shows the water regime class, D indicates a drained model cell.

This allowed a model evaluation at locations without measurements and at locations where the model was not calibrated to. The number of evaluation cells in each soil type was chosen according to the area covered by the corresponding soil type. The evaluation cells were selected in the center of the soil types to avoid influence from the boundaries. Figure 7 shows that the model does not differentiate between the water regime classes. In all the classes, there are dry and wet model cells. The underestimation of variability is a general behavior, dry locations (water regime class 1) are too wet, and wet locations (water regime classes 6 and 7) are too dry in the model. However, the model was able to predict the areas with the lowest groundwater levels. Model cells where the modeled groundwater level is deeper than 3 meters below the surface are only located in water regime class one (Fig. 7). Hence, the model was not able to reproduce the spatial variability in saturation durations, except for the locations with the lowest groundwater levels, even though it was calibrated on measured groundwater levels distributed throughout the catchment.

For a more complete picture of the modeled spatial distribution of the depth to groundwater in the catchment Fig. 8 shows a map of the model output from 27 July 2009. This is a situation with high groundwater levels after the largest rain event in the modeled period. Figure 8 reveals a clear dominance of the drainage system in the determination of the modeled groundwater level (compare Fig. 8 with Fig. 3c). This is also visible in Fig. 7. Most of the drained cells show a very similar behavior with stable groundwater levels around $1.5 \mathrm{~m}$ below the surface (the installation depth of the tile drains). A comparison of Fig. 8 with Fig. 3a reveals that the spatial pattern of the model output does not resemble 
Table 1. Deviations between observed and simulated water table levels in the 11 piezometers.

\begin{tabular}{lrrrrrrrrrrr}
\hline Piezometer & P1 & P2 & P3 & P4 & P5 & P6 & P7 & P8 & P9 & P10 & P11 \\
RMSE (mm) & 792 & 310 & 218 & 281 & 832 & 857 & 1001 & 328 & 441 & 411 & 1003 \\
\hline
\end{tabular}

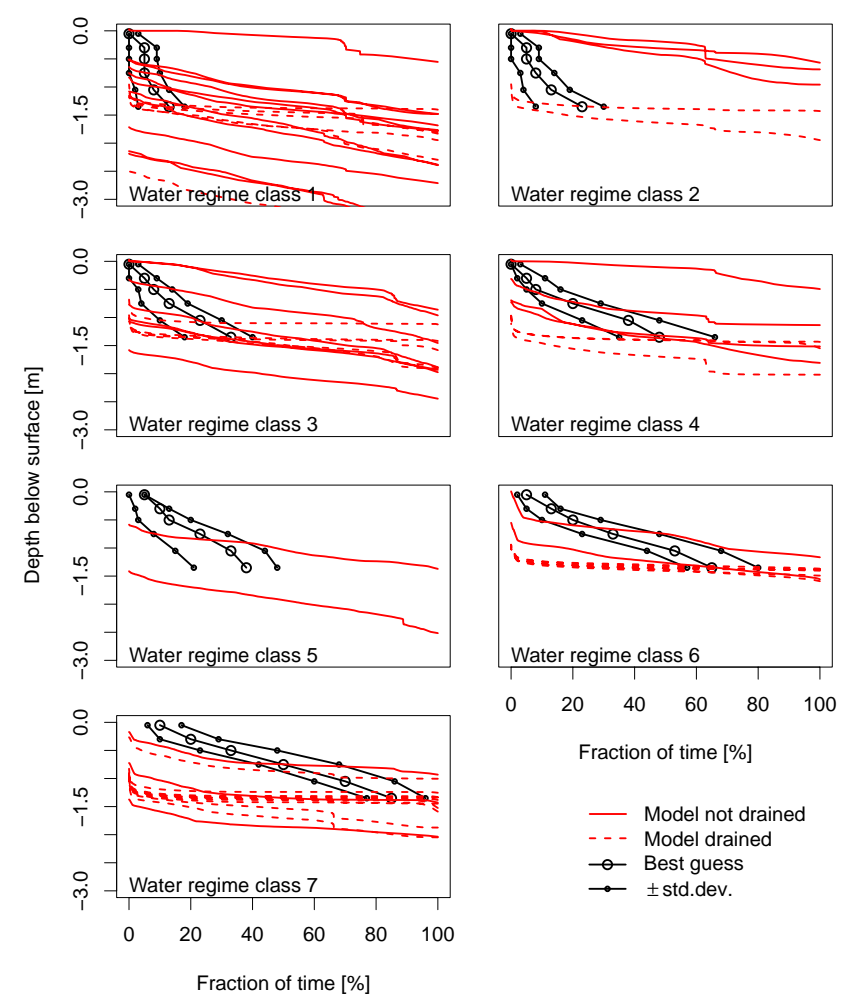

Figure 7. Comparison of the depth distribution of the saturation duration in selected model cells with the estimate from soil morphology. The model results are grouped into the respective water regime class and into drained and not drained cells.

the pattern observed in soil morphology. The spatial overlap between wet areas as estimated from the soil map (water regime classes 6 and 7) and the wettest $20 \%$ of the cells in the modeled output is only $12 \%$. Model and soil map would therefore predict completely different locations as CSAs. The model predicts high water tables in areas where it should be dry. In the center of the catchment, where the area is drained but still wet in reality, the model predicts too low water levels (compare Fig. 8 with Fig. 3c). It seems that the drainage system in the model is too efficient in lowering the groundwater table.

\section{Discussion}

\subsection{Soil map translation}

A meaningful validation of the saturation duration estimates from the soil map is not straightforward due to several

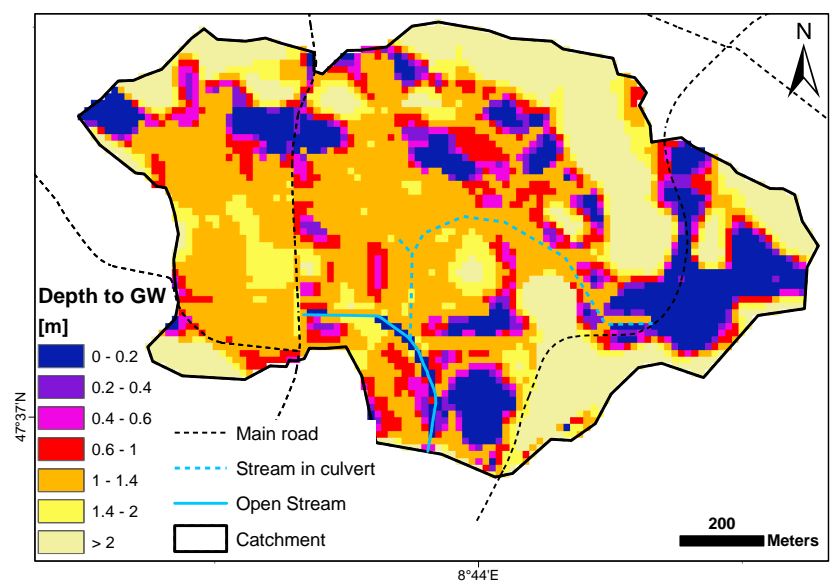

Figure 8. Map of the modeled depth to groundwater on 27 July 2009.

difficulties. First, the spatial coverage of the estimates corresponds to the soil map unit while piezometers are point measurements. Hence, deviations between soil map estimates and piezometer data may simply reflect local heterogeneities. Furthermore, the soil map divides the area into units with sharp boundaries. Some of these boundaries are in reality gradual changes. The vicinity of a piezometer to a soil unit boundary (especially boundaries between very wet and very dry soils) can therefore complicate a meaningful evaluation. A second difficulty is that the estimates do not differ heavily; the saturation estimates change gradually from one class to the next. The piezometer measurements could therefore fit well in more than one class. Third, there are temporal aspects of the validation. Soil morphology does not necessarily reflect the current water regime, especially when the water regime has recently changed because of artificial drainage. According to Hayes and Vepraskas (2000), soil drainage can alter morphology within decades. Finally, it is possible that the morphological signs of wetness do not evolve in a certain soil, even though the same water regime has persisted a longer time. A possibility for this is soil saturation without oxygen depletion (e.g., frequent but short periods of saturation), which does not lead to morphological changes (Evans and Franzmeier, 1986; Pickering and Veneman, 1984).

The main part of the drainage system in our study catchment was installed in the 1930s, the soil map was produced between 1988 and 1997. It can therefore be expected that soil morphology reflects the current situation. However, the interpretation of drained soils will, in general, remain difficult. 
The mismatch between the measured groundwater level and soil morphology at piezometer 1 shows the limitations of the approach. Soil morphology does not reflect the current water regime everywhere. As stated above, it is possible that the morphological signs of wetness did not evolve in this soil, even though the same water regime has persisted a longer time. On the other hand, the current water regime as measured in the piezometer could have developed only few years ago for several reasons, possibly because of a poorly maintained and clogged part of the drainage system, for example.

Despite these difficulties and limitations, the comparison of the estimates with the piezometric measurements shows a generally good agreement (Fig. 4). We are therefore confident that soil morphology in this region reflects the current water regime in most soils. The good agreement between the topographic wetness index and the map of the soil water regime classes indicates that the soil distribution with respect to soil saturation and soil water regime is strongly driven by topography in this catchment. In addition, this correspondence shows that the estimation of soil saturation from soil map information resulted in a reasonable spatial pattern of soil saturation in this catchment.

The quantitative interpretation of soil morphology will always remain uncertain to some degree. However, if the uncertainties can be quantified, such information can still be very valuable for model calibration and evaluation (Franks et al., 1998).

\subsection{Model predictions}

\subsubsection{Calibration}

We chose a model setup with a homogeneous saturated zone because the geological map does not indicate any spatial differentiation (swisstopo, 2007). Also soil texture in the study catchment is rather homogeneous. In addition, the soil texture classes in the Swiss classification system (FAL, 1997) are rather wide. Therefore, a spatial distribution based on geological information or texture information obtained from the soil map would not have resulted in much variability. The only spatially variable attributes in the saturated zone module were surface topography, surface connectivity and the existence of tile drainage. However, the unsaturated zone was spatially differentiated based on the water regime classes because we expect different thicknesses of the unsaturated zone in the water regime classes. This setup resulted in 83 parameters to be calibrated. Parameter optimization was therefore a rather complex problem with the simultaneous calibration to discharge and groundwater levels at 11 locations. We started the calibration at the optimum parameter set of a model setup with a homogeneous unsaturated zone. Some of the parameters did not differentiate into the nine unsaturated zones but remained at the starting parameter value for all or some of the soil types. The likelihood function was therefore insensitive to a spatial distribution of these parameters (these parameters are indicated in Tables S1 to S4 in the Supplement).

It could be argued that the poor model performance regarding water table levels is caused by a wrong subjective attribution of weights to the water table data in the aggregating likelihood function (Efstratiadis and Koutsoyiannis, 2010) (Sect. 2.5.4). Because we used such a single function we did not explicitly quantify the trade-offs between discharge and water table simulations. An imbalance in the weighting could be caused (i) by an unbalanced number of data points for the different variables or (ii) a disparity between the standard deviations attributed to the variables in the likelihood function (Eq. 23). The first possibility is excluded because the actual number of piezometric data exceed the discharge data by a factor of 11 (Sect. 2.5.4). The second possibility was avoided by the joint calibration of the standard deviations. We chose wide priors for all the error variances, so we did not force the model into a solution where only discharge was reproduced well. Hence, if there was a parameter set that performed well on some of the water table levels - causing the standard deviation to be small - it had outperformed data sets that performed only well on discharge.

Based on the arguments above we do not believe that the rather poor model performance with respect to groundwater level dynamics can be attributed to problems related to the chosen calibration procedure. We rather think that the problems arise from the model structure.

The analysis of residuals of the maximum likelihood solution during the calibration period revealed that the statistical assumptions behind our error models could be only partially fulfilled. Residuals of discharge showed a strong relationship with discharge itself in non-transformed space and no relationship in the transformed space (Supplement, Fig. S1). This suggests that the applied Box-Cox transformation was indeed useful and acted towards more homoscedastic discharge errors. The assumption of normality was mostly met for discharge in transformed space except for the slightly heavy tails in the residual distribution (outside the central $80 \%$ probability domain) (Supplement, Fig. S2). No transformation was applied for piezometer data, which was justified by the posterior lack of dependence between the magnitude of residuals and piezometer levels. The residuals of sites showing a poor fit in terms of mean groundwater level were certainly heavily biased, which violated the hypothesis that the expected value of errors was 0 (Supplement, Fig. S3). The distribution of residuals was quite far from normal for most sites. In accordance with the models ability to match mean piezometer levels much better than temporary peaks, residual distributions were all skewed to a varying degree (Supplement, Fig. S2). The assumption on the independence of residuals was neither fulfilled for discharge nor the piezometer data, especially some of the water level residuals were heavily autocorrelated (Supplement, Fig. S4). This suggests that autoregressive error models would have been statistically 
better choices than the independence assumption. However, in contrast to the width of predictive uncertainty interval and parameter values, the maximum likelihood fit for discharge series was often proven to be robust against neglecting the autocorrelation in residuals (Honti et al., 2013; Del Giudice et al., 2013). The large variability in the shape of the residual distributions and in the extent of autocorrelation suggests that - in a next calibration exercise - individual distributions and individual autoregressive errors should be assumed for the piezometers.

\subsubsection{Model performance}

The model is able to reproduce the general hydrological behavior of the catchment (Fig. 5 and Table 1). The satisfactory match between observed and modeled groundwater levels with a model that assumes homogeneous soil properties indicates that groundwater levels in this catchment are mainly driven by topography and are not strongly influenced by the variability of hydraulic soil properties. However, if we focus on the top two meters below soil surface there are deficiencies in the groundwater level predictions.

The comparison with the estimates of soil saturation reveals a lack of differentiation between wet and dry areas (Fig. 6) and wrong spatial patterns of soil saturation (Fig. 8). The main problems are (i) the missing dynamics in the groundwater levels, (ii) the dominance of the drainage system with respect to groundwater levels which leads to wrong spatial patterns of soil saturation and (iii) the homogeneity within the drained part of the catchment. These deficiencies are problematic if one wants to use such a model to predict critical source areas. Saturation-excess overland flow only occurs in situations with high groundwater levels. A prediction model therefore needs to be able to adequately reproduce groundwater dynamics especially in situations with high groundwater levels. Furthermore, large parts of the intensively cultivated cropping areas in Switzerland are artificially drained; the model should therefore be able to predict groundwater levels and their dynamics in drained areas. The prediction of saturation excess areas requires a very high accuracy in groundwater level prediction. A difference of $50 \mathrm{~cm}$ or less in the depth to groundwater is already crucial, because it decides whether an area often produces saturation-excess overland flow. Even though the model captured the general hydrological behavior of the catchment with respect to discharge and absolute groundwater levels, it was far from being useful as a prediction tool for saturated areas. It did not achieve the accuracy that is needed for practical applications.

Some of the deficiencies in water level dynamics were possibly caused by the chosen model structure. The current model only considers the effects of different antecedent soil moisture contents within the unsaturated zone. This influences the recharge to the saturated zone. However, within the saturated zone, antecedent soil moisture is neglected (constant effective porosity) and therefore has no influence on the increase of the water table during different events. Furthermore, effective porosity is the same during rising and falling water tables in the model. In reality however, the amount of water needed to increase the water level by a given level depends on the degree of saturation before the event. Additionally, the degree of saturation above a rising water table does not need to be the same than the degree of saturation above a falling water table. This can only be achieved by coupling the soil moisture dynamics in the unsaturated zone and the groundwater level dynamics in the saturated zone.

Because crops may differ strongly in their water requirements at any given moment, accounting for antecedent soil moisture may require the inclusion of crop specific water abstraction from the unsaturated zone. This may be actually a reason why the relative responses of the water table in different piezometers differed between events.

A further problem is the representation of the drainage system, which is a dominant feature in the hydrology of the catchment. Because most of the area has no direct connection to stream, i.e., surface runoff cannot directly reach the stream (Doppler et al., 2012), we know that most of the discharge reaches the water course through tile drains. At the same time, we know that the water table is often quite close to the soil surface despite the efficient drainage of the water through the soil. The current model version drains the soils too efficiently. In order to get as much water as possible during rain events through the soil while keeping the water table at a higher water level it is obvious that the water flux has to increase more strongly (in nonlinear fashion) with the water table than described by Eq. (21). Conceptually, this could be achieved by adding an additional preferential flow component that depends (in a nonlinear manner) on the current water level (see Frey et al., 2011, for a similar solution).

Especially in drained areas it is important to be aware of the difference in spatial support between piezometer readings and model predictions. Piezometers are point measurements while the model predictions are made on a $16 \mathrm{~m} \times 16 \mathrm{~m}$ grid. The tile drain spacing is around $15 \mathrm{~m}$. So the model does not resolve the difference between locations directly above tile drains and locations in the middle between tile drains. In reality however, this difference is important with regard to groundwater levels. If a piezometer is directly above a tile drain, the model would overestimate its groundwater level. But it would underestimate groundwater levels in between tile drains.

In the model, tile drains are represented as areas (all cells in an area with tile drains are treated as drained cells) while in reality the tile drains are linear features. The areal representation in the model prevents the buildup of high groundwater levels between drainage tubes and the corresponding high gradients between drainage tube and the undrained space between drainage tubes. If the tile drains should be implemented as linear features in a model, this would require a much higher spatial resolution. The rather low spatial resolution of our model setup $(16 \mathrm{~m})$ generally prevents the 
reproduction of very steep gradients on short distances which also influences the groundwater level dynamics.

Based on the available information on geology (swisstopo, 2007) and soil texture (FAL, 1997) there was no indication to spatially distribute the parameters of the saturated zone (see Sect. 4.2.1). If there was a parameter set within our model structure that would perform well on some of the piezometers (because the saturated zone parameters fit well for this soil type), this parameter set would have outperformed other solutions. But the maximum likelihood parameter set does not well reproduce groundwater level dynamics (especially in the peaks) of any piezometer. We do therefore believe that this rather poor model performance has to be attributed to the model structure and not to the calibration procedure or lack of spatial heterogeneity in the model.

A closer look at the piezometer data in Fig. 6 reveals that the level fluctuations of the shallow groundwater are rather complex even in the rather simple and homogeneous study catchment. Every piezometer reacts individually to the different rain events. Moreover, the dynamics of piezometers within the same water regime class differ substantially. Even if we consider whether a piezometer location is drained or not, it is impossible to explain the differences and similarities of the groundwater dynamics. It would have been possible that the model can explain the spatial variability of groundwater level dynamics if these dynamics are determined by a combination of topographic position, the soil water regime class and the drained areas. However, the discrepancy between modeled and measured groundwater levels indicates that other processes influence the groundwater levels to a degree that cannot be neglected. From a scientific point of view it would be interesting to dig deeper into these processes, trying to understand the influencing factors of the groundwater level dynamics. To do so, we suggest using a model with a more detailed representation of the processes at the boundary between the saturated and the unsaturated zone and a more realistic description of the drainage system. The former could possibly be achieved within a conceptual model as it was done by Seibert et al. (2003). The latter however, would require a spatially explicit drainage system representation with high spatial resolution. Such a model would need detailed information on the drainage system and its maintenance status, which is often not available.

In the light of the above discussion about a model that includes additional processes, it seems surprising that the spatial pattern of wet areas as predicted by the topographic wetness index is in better agreement with the soil map than the predictions of the more complex model (Figs. 3 and 8). A comparison to TOPMODEL predictions could therefore be interesting. According to TOPMODEL, the spatial groundwater level distribution is simply dependent on the distribution of the wetness index and the average moisture level in the catchment. At each location there is a constant offset to the mean depth of the water table in the catchment that depends on the deviation between the local wetness index and

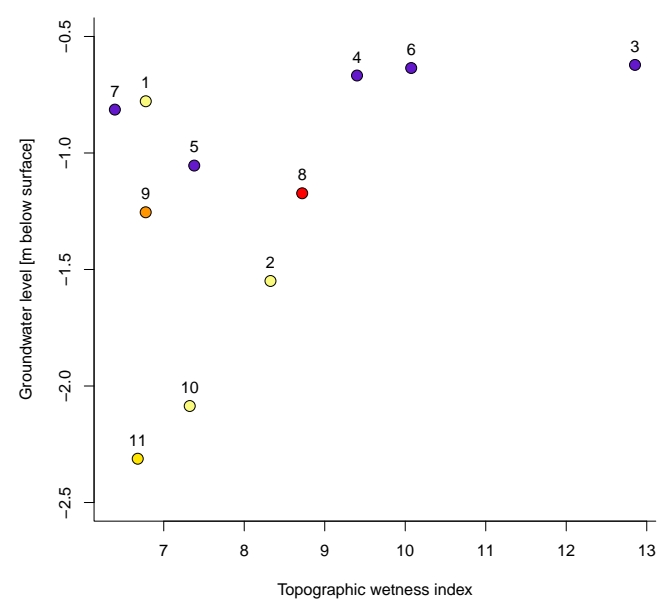

Figure 9. Average groundwater depth in the piezometers as a function of the local wetness index. Numbers refer to the piezometer number, colors to the corresponding soil water regime class.

its average value (Blazkova et al., 2002). Accordingly, one would expect the depth of the water table to be correlated with the local wetness index. Figure 9 depicts the average water level as a function of the wetness index. It is obvious that for low index values there is a large scatter of the data and for high index values the water table hardly depends on the index. We used a topographic wetness index that neglects local transmissivity. However, using a wetness index including transmissivity estimated from soil map information (as introduced by Beven, 1986) would not significantly change the spatial pattern because of the homogeneous soil texture and geology in the catchment (see above). Hence, a simple wetness index based approach does not outperform our model approach.

This conclusion is supported by the comparison of the dynamics of the different piezometers. According to the TOPMODEL approach, the water table dynamics at different topographical positions should simply be shifted in height of the water table (if one assumes a constant drainable porosity with depth). Figure 6 however, reveals that the dynamic varies substantially between the piezometers. Our approach mostly failed to reproduce these differences; conceptually TOPMODEL will do so as well.

So far we discussed identification of CSAs caused by saturation-excess overland flow. However, it was shown that areas that produce infiltration-excess overland flow can be CSA on arable land (Doppler et al., 2012). These areas depend strongly on the actual land management and they can change with crop rotation or when the management practices are changing. Therefore, their identification requires knowledge on the current local site conditions. As an example, Srinivasan and McDowell (2009) found that small trampled areas beside fences were relevant in the occurrence of infiltration-excess overland flow and the transport of phosphorus to the stream. Such features cannot be captured by 
models based on generally available information and - from a practical perspective - once they are identified in the field there is no need to implement them into a prediction model.

The focus of this study was to use a model that would be applicable for practical purposes. Besides model-based predictions, critical source areas can also be directly identified in the field by experts. This requires interviews with the local farmers and detailed site inspections. If a prediction model for CSAs should serve as basis for pollution mitigation measures, it must have advantages as compared to field visits by experts. An advantage of model predictions would be that predictions can be based on existing knowledge, so that field visits would not be necessary. However, the need for very detailed knowledge (e.g., on the drainage system and on the actual land management) cancels this advantage. Additionally, the demanding setup of a very detailed model, its calibration, and tests in every small catchment (not to mention uncertainty analysis), would not lead to a time gain compared to field visits by experts to directly identify CSAs in the field.

\section{Conclusions and outlook}

Our case study has shown that the estimation of saturation durations from morphological soil map information is possible and these estimates have proven to be useful for model validation even though the resulting map of duration of soil saturation remains uncertain to some degree because the estimates do not always represent the current water regime. The additional data source provides quantitative spatial information on the soil water regime that can be used as validation data for the predicted spatial patterns. In a further step such estimates could also be used to calibrate spatially distributed hydrological models, so that no groundwater level measurements are needed for model calibration.

The model was able to reproduce the general hydrological behavior of the catchment. However, the desired accuracy of the groundwater level predictions - which is needed for the identification of CSAs - could not be achieved. The processes that determine the groundwater level dynamics in this catchment seem to be more complex than the used model. It seems that a high spatial resolution and detailed process representations are needed for a groundwater level prediction that is accurate enough for the identification of CSAs in practical situations. Drained areas are especially challenging for the following reasons: limited data availability on tile drain locations and maintenance status, difficult integration in catchment models (concept and spatial resolution), and finally the estimation of soil saturation duration is much more difficult in drained areas.

Our results indicate that dynamic, spatially distributed hydrological models to predict CSAs are still far from being useful for management decisions. If a model should be accurate enough and should also include infiltration excess areas, it would require information that is not generally available.
Furthermore, the setup and test of such a complex model would need more resources than direct observations of CSAs in the field by experts and the local farmers. If site specific management of CSAs should be achieved, we recommend identifying these areas in the field and not solely by model predictions. However, predictions by simple models like the topographic wetness index can be helpful for the identification of CSAs in the field. It would also be interesting to test the predictive capabilities of different modeling concepts under real world conditions.

\section{The Supplement related to this article is available online at doi:10.5194/hess-18-3481-2014-supplement.}

Acknowledgements. The field work would not have been possible without Ivo Strahm, Luca Winiger, Marcel Gay and Hans Wunderli. We also would like to acknowledge the local farmers for their cooperation. Comments by the referees significantly improved the quality of the manuscript. We gratefully acknowledge the funding by the Swiss Federal Office for the Environment (FOEN).

Edited by: J. Freer

\section{References}

Abbott, M. B., Bathurst, J. C., Cunge, J. A., O'Connell, P. E., and Rasmussen, J.: An introduction to the European Hydrological System - Systeme Hydrologique Européen, "SHE", 1: history and philosophy of a physically-based, distributed modelling system, J. Hydrol., 87, 45-59, 1986.

Agnew, L. J., Lyon, S., Gérard-Marchant, P., Collins, V. B., Lembo, A. J., Steenhuis, T. S., and Walter, M. T.: Identifying hydrologically sensitive areas: bridging the gap between science and application, J. Environ. Manage., 78, 63-76, 2006.

Allen, R. G., Pereira, L. S., Raes, D., and Smith, M.: Crop evapotranspiration - Guidelines for computing crop water requirements - FAO Irrigation and drainage paper 56, FAO - Food and Agriculture Organization of the United Nations, Rome, 1998.

Ambroise, B.: Variable "active" versus "contributing" areas or periods: a necessary distinction, Hydrol. Process., 18, 1149-1155, 2004.

Beers, W. F. J.: Computing drain spacings, Wageningen, International institute for land reclamation and improvement, 1976.

Beven, K. J.: Hillslope Runoff Processes and Flood Frequency Characteristics, in: Hillslope Processes, edited by: Abrahams, A. D., Allen and Unwin, Boston, 187-202, 1986.

Beven, K. J. and Kirkby, M. J.: A physically based, variable contributing area model of basin hydrology, Hydrolog. Sci. J., 24, 43-69, 1979.

Blazkova, S., Beven, K. J., and Kulasova, A.: On constraining TOPMODEL hydrograph simulations using partial saturated area information, Hydrol. Process., 16, 441-458, 2002.

Boorman, D. B., Hollis, J. M., and Lilly, A.: Hydrology of soil types: a hydrologically-based classification of the soils 
of the United Kingdom, Inst. Hydrol., Wallingford, available at: http://www.ceh.ac.uk/products/publications/documents/ ih126hydrologyofsoiltypes.pdf (last access: 28 October 2013), 1995.

Borah, D. K. and Bera, M.: Watershed-scale hydrologic and nonpoint-source pollution models: review of mathematical bases, T. Asae, 46, 1553-1566, 2003.

Box, G. E. P. and Cox, D. R.: An analysis of transformations, J. Roy. Stat. Soc. B, 26, 211-252, 1964.

Box, G. E. P. and Cox, D. R.: An analysis of transformations revisited, rebutted, J. Am. Stat. Assoc., 77, 209-210, 1982.

Brunner, P. and Simmons, C. T.: HydroGeoSphere: A Fully Integrated, Physically Based Hydrological Model, Ground Water, 50, 1745-6584, 2012.

Del Giudice, D., Honti, M., Scheidegger, A., Albert, C., Reichert, P., and Rieckermann, J.: Improving uncertainty estimation in urban hydrological modeling by statistically describing bias, Hydrol. Earth Syst. Sci., 17, 4209-4225, doi:10.5194/hess-17-42092013, 2013.

Doppler, T., Camenzuli, L., Hirzel, G., Krauss, M., Lück, A., and Stamm, C.: Spatial variability of herbicide mobilisation and transport at catchment scale: insights from a field experiment, Hydrol. Earth Syst. Sci., 16, 1947-1967, doi:10.5194/hess-161947-2012, 2012.

Dunn, S. M. and Lilly, A.: Investigating the relationship between a soil classification and the spatial parameters of a conceptual catchment-scale hydrological model, J. Hydrol., 252, 157-173, 2001.

Easton, Z. M., Fuka, D. R., Walter, M. T., Cowan, D. M., Schneiderman, E. M., and Steenhuis, T. S.: Re-conceptualizing the soil and water assessment tool (SWAT) model to predict runoff from variable source areas, J. Hydrol., 348, 279-291, 2008.

Efstratiadis, A. and Koutsoyiannis, D.: One decade of multiobjective calibration approaches in hydrological modelling: a review, Hydrolog. Sci. J., 55, 58-78, 2010.

Einsele, G: Sedimentary Basins: Evolution, Facies, and Sediment Budget, 2nd Edn., Springer, Berlin, 2000.

Evans, C. V. and Franzmeier, D. P.: Saturation, aeration, and color patterns in a toposequence of soils in North-Central Indiana, Soil Sci. Soc. Am. J., 50, 975-980, 1986.

FAL: Bodenkarte Kanton Zürich 1: 5000, Eidgenössische Forschungsanstalt für Agrarökologie und Landbau Zürich, Zürich, 1997.

Franks, S. W., Gineste, P., Beven, K. J., and Merot, P.: On constraining the predictions of a distributed model: the incorporation of fuzzy estimates of saturated areas into the calibration process, Water Resour. Res., 34, 787-797, 1998.

Franzmeier, D. P., Yahner, J. E., Steinhardt, G. C., and Sinclair, H. R.: Color patterns and water-table levels in some indiana soils, Soil Sci. Soc. Am. J., 47, 1196-1202, 1983.

Freer, J. E., McMillan, H., McDonnell, J. J., and Beven, K. J.: Constraining dynamic TOPMODEL responses for imprecise water table information using fuzzy rule based performance measures, J. Hydrol., 291, 254-277, 2004.

Frey, M. P., Schneider, M. K., Dietzel, A., Reichert, P., and Stamm, C.: Predicting critical source areas for diffuse herbicide losses to surface waters: role of connectivity and boundary conditions, J. Hydrol., 365, 23-36, 2009.
Frey, M. P., Stamm, C., Schneider, M. K., and Reichert, P.: Using discharge data to reduce structural deficits in a hydrological model with a Bayesian inference approach and the implications for the prediction of critical source areas, Water Resour. Res., 47, W12529, doi:10.1029/2010WR009993, 2011.

Gallart, F., Latron, J., Llorens, P., and Beven, K.: Using internal catchment information to reduce the uncertainty of discharge and baseflow predictions, Adv. Water Resour., 30, 808-823, 2007.

Gemeinde Ossingen: Drainagenkarte 1 : 1000, Flurgenossenschaft Gemeinde Ossingen, Ossingen, 1995.

Gemeinde Ossingen: Entwässerungsplan der Gemeinde Ossingen, Gemeinde Ossingen, Ossingen, 2008.

Gerits, J. J. P., de Lima, J. L. M. P., and van den Broek, T. M. W.: Overland flow and erosion, in: Process Studies in Hillsope Hydrology, edited by: Anderson, M. G. and Burt, T. P., Wiley, Chichester, 173-214, 1990.

Gomides Freitas, L., Singer, H., Müller, S. R., Schwarzenbach, R. P., and Stamm, C.: Source area effects on herbicide losses to surface waters - a case study in the Swiss Plateau, Agr. Ecosyst. Environ., 128, 177-184, 2008.

Grabs, T., Seibert, J., Bishop, K., and Laudon, H.: Modeling spatial patterns of saturated areas: a comparison of the topographic wetness index and a dynamic distributed model, J. Hydrol., 373, 15-23, 2009.

Grayson, R. B., Moore, I. D., and McMahon, T. A.: Physically based hydrologic modeling 1. a terrain-based model for investigative purposes, Water Resour. Res., 26, 2639-2658, 1992a.

Grayson, R. B., Moore, I. D., and McMahon, T. A.: Physically based hydrologic modeling 2 . is the concept realistic?, Water Resour. Res., 26, 2659-2666, 1992b.

Güntner, A., Seibert, J., and Uhlenbrook, S.: Modeling spatial patterns of saturated areas: an evaluation of different terrain indices, Water Resour. Res., 40, W05114, doi:10.1029/2003WR002864, 2004.

Gupta, H. V., Sorooshian, S., and Yapo, P. O.: Toward improved calibration of hydrologic models: Multiple and noncommensurable measures of information, Water Resour. Res., 34, 751-763, 1998.

Hahn, C., Prasuhn, V., Stamm, C., Lazzarotto, P., Evangelou, M. W. H., and Schulin, R.: Prediction of dissolved reactive phosphorus losses from small agricultural catchments: calibration and validation of a parsimonious model, Hydrol. Earth Syst. Sci., 17, 3679-3693, doi:10.5194/hess-17-3679-2013, 2013.

Hayes, W. A. and Vepraskas, M. J.: Morphological changes in soils produced when hydrology is altered by ditching, Soil Sci. Soc. Am. J., 64, 1893-1904, 2000.

Heathwaite, A. L., Quinn, P. F., and Hewett, C. J. M.: Modelling and managing critical source areas of diffuse pollution from agricultural land using flow connectivity simulation, J. Hydrol., 304, 446-461, 2005.

Hindmarsh, A. C.: A systematized collection of ODE solvers, in: IMACS Transactions on Scientific Computation, edited by: Stepleman, R. S., Scientific Computing, Amsterdam, 55-64, 1983.

Honti, M., Stamm, C., and Recihert, P.: Integrated uncertainty assessment of discharge predictions with a statistical error model, Water Resour. Res., 49, 4866-4884, doi:10.1002/wrcr.20374, 2013.

Hrachowitz, M., Savenije, H. H. G., Blöschl, G., McDonnell, J. J., Sivapalan, M., Pomeroy, J. W., Arheimer, B., Blume, T., 
Clark, M. P., Ehret, U., Fenicia, F., Freer, J. E., Gelfan, A., Gupta, H. V., Hughes, D. A., Hut, R. W., Montanari, A., Pande, S., Tetzlaff, D., Troch, P. A., Uhlenbrook, S., Wagener, T., Winsemius, H. C., Woods, R. A., Zehe, E., and Cudennec, C.: A decade of Predictions in Ungauged Basins (PUB) - a review, Hydrolog. Sci. J., 58, 1198-1255, 2013.

Jacobs, P. M., West, L. T., and Shaw, J. N.: Redoximorphic features as indicators of seasonal saturation, Lowndes County, Georgia, Soil Sci. Soc. Am. J., 66, 315-323, 2002.

Kennedy, J. and Eberhart, R.: Particle swarm optimization, in: Proceedings of the International Conference on Neural Networks (IEEE), Vol. 4, Perth, Australia, 1942-1948, doi:10.1109/ICNN.1995.488968, 1995.

Lamb, R., Beven, K., and Myrabø, S.: Use of spatially distributed water table observations to constrain uncertainty in a rainfallrunoff model, Adv. Water Resour., 22, 305-317, 1998.

Lazzarotto, P., Stamm, C., Prasuhn, V., and Flühler, H.: A parsimonious soil-type based rainfall-runoff model simultaneously tested in four small agricultural catchments, J. Hydrol., 321, 21-38, 2006.

Leu, C., Singer, H., Stamm, C., Müller, S. R., and Schwarzenbach, R. P.: Simultaneous assessment of sources, processes, and factors influencing herbicide losses to surface waters in a small agricultural catchment, Environ. Sci. Technol., 38, 3827-3834, 2004a.

Leu, C., Singer, H., Stamm, C., Müller, S. R., and Schwarzenbach, R. P.: Variability of herbicide losses from 13 fields to surface water within a small catchment after a controlled herbicide application, Environ. Sci. Technol., 38, 3835-3841, 2004b.

Louchart, X., Voltz, M., Andrieux, P., and Moussa, R.: Herbicide transport to surface waters at field and watershed scales in a Mediterranean vineyard area, J. Environ. Qual., 30, 982-991, 2001

Lyon, S. W., McHale, M. R., Walter, M. T., and Steenhuis, T. S.: The impact of runoff generation mechanisms on the location of critical source areas, J. Am. Water Resour. As., 42, 793-804, 2006.

Madsen, H.: Parameter estimation in distributed hydrological catchment modelling using automatic calibration with multiple objectives, Adv. Water Res., 26, 205-216, 2003.

Maréchal, D. and Holman, I. P.: Development and application of a soil classification-based conceptual catchment-scale hydrological model, J. Hydrol., 312, 277-293, 2005.

MeteoSchweiz: available at: http://www.meteoschweiz.admin. ch/web/de/services/datenportal.html (last access: 8 September 2014), 2009.

Montagne, D., Cornu, S., Le Forestier, L., and Cousin, I.: Soil drainage as an active agent of recent soil evolution: a review, Pedosphere, 19, 1-13, 2009.

Morgan, C. P. and Stolt, M. H.: Soil morphology-water table cumulative duration relationships in southern New England, Soil Sci. Soc. Am. J., 70, 816-824, 2006.

Nash, J. E. and Sutcliffe, J. V.: River flow forcasting through conceptual models - Part 1: A discussion of principles, J. Hydrol., 10, 282-290, 1970.

Nelder, J. A. and Mead, R.: A simplex method for function minimization, Comput. J., 7, 308-313, 1965.
Petzold, L.: Automatic selection of methods for solving stiff and nonstiff systems of ordinary differential equations, SIAM J. Sci. Stat. Comp., 4, 136-148, 1983.

Pickering, E. W. and Veneman, P. L. M.: Moisture regimes and morphological-characteristics in a hydrosequence in Central Massachusetts, Soil Sci. Soc. Am. J., 48, 113-118, 1984.

Pionke, H. B., Gburek, W. J., Sharpley, A. N., and Schnabel, R. R.: Flow and nutrient export patterns for an agricultural hill-land watershed, Water Resour. Res., 32, 1795-1804, 1996.

Refsgaard, J. C., Storm, B., and Clausen, T.: Système Hydrologique Européen (SHE): review and perspectives after 30 years development in distributed physically-based hydrological modelling, Hydrol. Res., 41, 355-377, 2010.

Reichert, P. and Schuwirth, N.: Linking statistical bias description to multiobjective model calibration, Water Resour. Res., 48 , W09543, doi:10.1029/2011WR011391, 2012.

Schneider, M. K., Brunner, F., Hollis, J. M., and Stamm, C.: Towards a hydrological classification of European soils: preliminary test of its predictive power for the base flow index using river discharge data, Hydrol. Earth Syst. Sci., 11, 1501-1513, doi:10.5194/hess-11-1501-2007, 2007.

Seibert, J., Rodhe, A., and Bishop, K.: Simulating interactions between saturated and unsaturated storage in a conceptual runoff model, Hydrol. Process., 17, 379-390, 2003.

Simonson, G. H. and Boersma, L.: Soil morphology and water table relations: 2. correlation between annual water table fluctuations and profile features, Soil Sci. Soc. Am. Pro., 36, 649-653, 1972.

Srinivasan, M. S. and McDowell, R. W.: Identifying critical source areas for water quality: 1 . mapping and validating transport areas in three headwater catchments in Otago, New Zealand, J. Hydrol., 379, 54-67, 2009.

swisstopo: DTM ${ }^{{ }^{\circ}}$ 2003, reproduced with permission of swisstopo, JA100119, Wabern, Switzerland, 2003.

swisstopo: Geologischer Atlas der Schweiz ${ }^{\circledR} 2007$, reproduced with permission of swisstopo, Wabern, JA100119, Switzerland, 2007.

swisstopo: Vector $25{ }^{{ }^{\odot}} 2008$, reproduced with permission of swisstopo, JA100119, Wabern, Switzerland, 2008.

Tarboton, D. G.: A new method for the determination of flow directions and upslope areas in grid digital elevation models, Water Resour. Res., 33, 309-319, 1997.

Terribile, F., Coppola, A., Langella, G., Martina, M., and Basile, A.: Potential and limitations of using soil mapping information to understand landscape hydrology, Hydrol. Earth Syst. Sci., 15, 3895-3933, doi:10.5194/hess-15-3895-2011, 2011.

Vepraskas, M. J. and Wilding, L. P.: Aquic moisture regimes in soils with and without low chroma colors, Soil Sci. Soc. Am. J., 47, 280-285, 1983.

Weiler, M. and McDonnell, J.: Virtual experiments: a new approach for improving process conceptualization in hillslope hydrology, J. Hydrol., 285, 3-18, 2004.

Wittmer, I. K.: Influence of agricultural pesticide and urban biocide use on load dynamics in surface waters, Ph.D. thesis, Swiss Federal Institute of Technology, Zürich (ETH), 2010. 